\title{
Hotel Customer Loyalty: The Effect of Individual's Similarity to Brand, Lifestyle Congruency and Cultural Brand Asset
}

\author{
Shahnaz Nayebzadeh*, Maryam Farmani \\ Department of Management, Yazd Branch, Islamic Azad University, Yazd, Iran
}

\begin{abstract}
Keywords:

Cultural Brand Asset, Brand Awareness, Perceived Quality, Brand Association, Individual's Similarity to Brand, Lifestyle Congruency

\section{Received}

17 November 2017

Received in revised form 28 June 2018

Accepted

21 July 2018

Correspondence:

Snayebzadeh@iauyazd.ac.ir

The main aim of this study was to investigate the factors affecting on customer loyalty of Mehr chain hotels in Yazd. Independent variables of this study included cultural brand asset, individual's similarity to brand, lifestyle congruency, intermediate variables of study included brand awareness, perceived quality, brand association, and customer satisfaction, and the dependent variable of study included brand loyalty. The population of this study included Iranian and non-Iranian quests of Mehr chain hotels of Yazd. Simple and stratified random sampling methods were used. Four hundred and thirty-five questionnaires (325 Persian questionnaires, and 110 English questionnaires) were distributed and gathered. Data were analyzed using the SPSS 18 Software. The relationships between variables and factors were confirmed through confirmatory factor analysis and structural equation modeling techniques using LISREL8.72 software. The results confirmed the impact of cultural brand assets on perceived quality, brand awareness, and brand association. Additionally, it was found that there was significant correlation between brand awareness, perceived quality, and brand association. Perceived quality, brand association, and customer satisfaction also have a positive impact on brand loyalty. Lifestyle congruency and individual's similarity to brand have impact on customer satisfaction. In this research after investigating the factors affecting on customer loyalty of Mehr chain hotels in Yazd, university sector entered in such research areas until both marketers as well as researchers to use the findings for increasing consumer loyalty.
\end{abstract}

CAIMI Journals

In recent years, several economic enterprises, from newly established small companies to international companies, have understood the importance of customer loyalty. All of them 
have understood that maintaining the current customer is more profitable than attracting new customer (Allameh \& Noktedan, 2010). Tourism industry is one of the largest industries in the world, if we do not say that it is the largest industry in Earth. As hotel is one of the tourism subsets, it plays an important role in turnover and income of this industry (Dehdashti Shahrokh, Jafarzadeh, \& Bakhshizadeh, 2012).

Customer loyalty is one of the key factors in successful marketing programs. Considering the importance of brand loyalty, Assael (1984) argues that marketing success of companies does not mean establishing the first purchase, but it involves frequent purchasing by customer (Ghaffari, Ranjbaran, Fathi, 2014). Customer loyalty has a positive impact on sale, a share of the budget, and maintaining the customer. Satisfied long-run customers will probably purchase more services and develop more verbal communications compared to short-term customers (Khajouie \& NaebZadeh, 2013).

Brand loyalty, as a structure, is based on consumer that its concept has been pre-specified through behavioral responses and psychological perception at present and previous periods (Youl ha, Jhon, Janda, \& Siva, 2009). Some of the factors influencing brand loyalty include customer satisfaction, individual's similarity to brand, lifestyle congruency, perceived quality, brand association, brand awareness, and cultural brand asset. Customer satisfaction is a key factor in shaping customers' willingness to purchase in future (Haghighi, Moghimi, \& Kymasy, 2003). Self-concept refers to a degree of an ideal and actual self-meaning of customer that is simultaneous with brand image (Nam, Ekinci, \& Whatt, 2011). Another factor is the individual's similarity to brand reflecting the evaluation of people of themselves in achieving goal in order to create an image of their identity (Ekinci, Dawes, \& Massy, 2008). Lifestyle congruency is another factor of a unique model of life influenced by individual behaviors (Dehdashti Shahrokh, et al., 2012).

Considering perceived quality as a factor affecting brand loyalty, it can be said that it is the customers' judgment of advantage, excellence, credibility and difference of a brand compared to rival brands. Another factor is brand association that can be observed in forms and features related to a product and independent aspects of the product kept in the customer's mind. Brand awareness is defined as an area where customers identify, recognize, and remember the brand and can identify related products and services (Rahimnia, Fatemi, \& Harandi, 2013). Cultural brand asset, as cultural symbol of a city, can create competitive advantage, and it is known as potential asset of brand (Kladou \& Khagias, 2014). According to the issues discussed, the main objective of this study is to examine the factors that affect customer loyalty in Mehr chain hotels and the effects of these variables on each other.

\section{Theoretical Foundations and Developing Hypotheses}

\section{Brand}

It is argued that brand is to identify the products or service or a group of sellers distinguishing product and service from their rival products (ZarghamBoroujeni \& Barzani, 2013). In marketing of brands, the starting point is usually making a distinction between presented products and services and current products and services. Due to advantages of branding for organization and consumers, it has been seriously considered by marketers (Moody, MirKazemi, \& Vahdani). 


\section{Brand Loyalty and Factors Affecting It}

The best definition of brand loyalty has been presented by Oliver (1999). He stated that it reflects a deep sustainable commitment to repurchase a product. It is being permanent customer for a product and preferable service in future (Dehdashti Shahrokh et al., 2012). Brand loyalty is considered as presence of a long-term non-randomized behavioral response resulted from mental purchase process of a brand (MotahariNejad, Samadi, Tulani, \& Pour Ashraf 2014). In this section, a number of factors affecting the brand loyalty are presented.

\section{Cultural Brand Asset}

Brand is an intangible asset of a product or service involving many parameters, including name, term, sign, symbol, logo, design, mental history of customers and consumers, authenticity, trust, and lasting credibility among customers. Cultural asset can be seen as a brand asset. Naturally, cultural symbols are specific for potential cultural brand asset. These assets are monuments / heritage, events, the civilization, food, traditions, contribution to world heritage, museums, and art centers (Kladou \& kehagias, 2014).

\section{Brand Awareness}

Brand awareness is level of awareness and knowledge in which customers identify and remember a brand and they identify the products and services related to the brand. Brand awareness refers to severity of association of features created in mind enabling customers to identify the brand at various situations and remember it, when needed. Brand awareness is defined in the form of customer's ability to associate the brand with particular needed product category (Rahimnia et al, 2013).

\section{Cultural Brand Asset Relationship with Brand Awareness}

In short, unique asset affects brand awareness. Therefore, it may attract more tourists. In addition, known asset can help customer remember and identify the brand. In addition, it helps in updating their role as tolerable tourism product.

In a study, Ruzzier (2010) examined the perspective of the demand in tourism destination phenomenon. The statistical population of study was German and Croatia tourists whose destination was two countries of Germany and Slovenia. The results suggest that the concept of the image traditionally represents the most important dimension in the evaluation of one part. However, for a more comprehensive evaluation of tourism destination dimensions, knowledge, quality and loyalty should be added (Ruzzier, 2010). The results of Kladou and Kehagias's (2014) study on evaluation of structural relationship between brand equity dimensions showed that when five dimensions of brand equity and cultural brand equity were combined, the importance of cultural brand asset is revealed for brand equity. In addition, this study provides useful theoretical insight by examining the structural relationships between brand equity dimensions and their impact on loyalty (Kladou \& Kehagias, 2014).

\section{Perceived Quality}

Perceived quality is the general and intangible feeling of a person to brand. It is based on the overall dimensions including characteristics of the product. Identifying the perceived quality, 
identification and assessment of its dimensions are important, but it should not be forgotten that perceived quality is a general impression. Perceived quality is a competitive necessity and most companies turn to customer quality as a strategic weapon, nowadays (Imani Khoshkhu \& Ayubi Yazdi, 2010).

\section{The Relationship between Brand Awareness and Perceived Quality}

Perceived quality is not a real quality of product, but it is a subjective evaluation of the product by customers, especially when price of the brand or characteristics of the product change. This variable is measured by indicators such as willingness to repurchase, recommend the brand to others, and commitment to the brand. Consumer awareness of the brand leads to perceived quality of the brand and brand association, affecting brand loyalty (Buil, Martinze, \& de Chernatony, 2013). Hakala et al (2012) studied the dimensions of the consumer-based brand equity and they stated that four dimensions of brand equity depend on cultural area. Results also revealed the relationship between TOMA (high mental awareness) and national area generalized to three categories of product (Hakala et al., 2012).

\section{Relationship between Perceived Quality and Brand Loyalty}

Brand perceived quality and brand association show the previous step guide to brand loyalty. Brand loyalty is a deep commitment to brand. When customers achieve higher positive perception of brand, it leads to loyalty. Previous studies suggest that higher level of perceived quality and positive associations can increases brand loyalty (Buil et al., 2013). Seric et al (2014) examined the customer's view and outlook and they reported the impact of integrated marketing communication on hotel equity. In addition, the mediating role of technology on these relationships was examined. Results indicate the positive relationships between studied structures, but the mediating role of technology was not confirmed (Seric, Gil-Saura, \& RuizMolina, 2014).

\section{Brand Association}

Brand association is defined as specific meaning of brand for customer. It includes assets related to brand subjectively (Ghilani Nia \& Musavian, 2010). Brand association includes thoughts and ideas shaped in people mind and it is associated with a special product and service. It includes power, utility, and perceived features that are usually represent advantages resulted from brand (Rahimnia et al., 2013).

\section{Relationship between Brand Awareness and Brand Association}

The structure of brand equity starts from brand awareness. Consumers should aware of brand firstly. Then, they should achieve a set of associations related to brand. Brand awareness is affected by power shaping of brand association such as perceived quality (Buil et al., 2013). Buil et al. (2013) investigated the effects of two types of advertising sale, monetary and nonmonetary advertising. They discovered the relationship between brand equity dimensions. The statistical population of study is Birmingham city of England for its sportswear brands of Adidas and Nike, and electronics brands of Sony and Panasonic, and car brands of BMW and Volkswagen. Sample of study included 302 subjects. The findings show that people attitude 
toward advertising plays a key role in dimensions of brand equity, while advertising on studied brands improved the brand awareness, but it is not enough for positive influence on brand association and perceived quality (Buil et al., 2013).

\section{Relationship between Brand Association and Brand Loyalty}

Quality and associations are important dimensions of brand equity increasing loyalty. Literature suggests positive impact of image on loyalty as well as positive relationship between quality and loyalty (Keladou \& Kehagias, 2014). Associations represent a base for purchase decisions for brand loyalty and creator of value for company and customers (SeyedJavadein \& Shams, 2007). Lu, Gursoy, and Lu (2015) examined the relationship between consumers' perception of authenticity and four dimensions of brand equity (brand awareness, brand association, perceived quality and brand loyalty) as well as integration of these four dimensions and the effect of brand equity on the choice of consumers for local restaurants. Their results show that authenticity perception is a key determinant of brand equity and it has significant impact on the choice of consumers to purchase (Lu, Gursoy, \& $\mathrm{Lu}, 2015)$.

\section{Individual's Similarity to Brand}

The term "self-concept" describes the homogeneity between self-meaning and brand personality. Brand personality is resulted from features that human gives to brand. Selfmeaning is resulted from a total of thought and feeling of people referring to themselves as an object. Individual's similarity to brand is related to an idea that person likes or wants to be similar to it (Huber, Vollhardt, Matthes, \&Vogle, 2010).

\section{Customer Satisfaction}

Customer satisfaction is feeling or attitude of a customer towards a product or service after receiving it. The customer satisfaction is the result of comparing processes between reality of product or service or social expectations and norms with respect to the product (Javanmard \& Hosseini, 2013). The customer satisfaction as the degree to which actual performance of company meets the customer expectations. If the company performance can meet the customer expectations, customer will be satisfied. Otherwise, he will be unsatisfied (Hosseini \& Rezaei, 2011).

\section{The Relationship between Individual's Similarity to Brand and Customer Satisfaction} Individual's similarity to brand is a determining factor in predicting the behavior of others, affecting return intention, recommend to others, positive attitude towards destination, customer satisfaction and loyalty, in turn. Most of commercial hotel guests select the highly cost hotels not merely due to convenient rooms, but also due to individual's similarity to brand (Dehdashti Shahrokh et al., 2012). Ahn, Ekinci, and Li (2013) examined the effects of self- homogeneity and functional congruency in selecting destination of tourists among residents in South East England. Considering the results, it is suggested that selection of destination by tourists is strongly affected by functional congruency rather than selfhomogeneity (Ahn et al., 2013). 


\section{The Relationship between Customer Satisfaction and Brand Loyalty}

Brand loyalty that is the customers' frequent preferring of one brand over others is specified by customers who experience the highest level of satisfaction. When customers are satisfied, they decide to repurchase the product or service leading to increased brand loyalty. Satisfied consumers will be probably loyal customers (Khajouie \& NaebZadeh, 2013). Nam et al. (2011) investigated the mediating effects of consumer satisfaction on the relationship between customer-based brand equity and brand loyalty in the hotel and restaurant industry of England English nationals. The findings of this study show that the consumer satisfaction has impact on staff behavior. Physical quality and lifestyle congruency effects on brand loyalty are completely mediated by customer satisfaction (Nam et al., 2011).

\section{Lifestyle Congruency}

Lifestyle is unique life model of one person stated by activities, interests, and ideas. Lifestyle includes common values, tasting in consumption patterns, and it includes symbolic nuance in various groups. Lifestyle congruency is defined as degree of match or mismatch between brand destination experience and desirable or actual lifestyle of tourists (Ahn et al., 2013). In its large-scale, lifestyle not only covers a group of features, but also it covers attitude to life, beliefs, and ideal (Nam et al., 2011). In many cases, only certain class of people is main consumers of a certain product or service. This helps marketers design their marketing plan based on their customers wants and views and achieve to more potential customers. If the degree of brand image matching with lifestyle of consumers increases, customer satisfaction with brand image will increase (Dehdashti Shahrokh et al., 2012). Ahn et al (2013) evaluated the symbolic meaning of consumption for tourism destination brands using self-consumption and cultural and social theories to examine the symbolic effect of brand consumption on destination brand loyalty. Results showed that three dimensions of tourism symbolic destination validate individual's similarity to brand, brand identification, and life congruency affecting the destination brand loyalty (Ahn et al, 2013). In examining the tourist loyalty to cultural locations, Chen, Peng, and Hung (2015) examined the factors that help in decision of tourisms to see cultural locations of Taiwan. The results showed that tourists usually like to re-visit and recommend these cultural locations for others increasing their self-image and supports their lifestyle, in other words, when tourisms see or want to live in an artistic way (Chen et al., 2015).

Considering the theoretical foundations mentioned before, in order to achieve the main objective and secondary objectives of the study, the following hypotheses are proposed and tested:

$\mathbf{H}_{1}$ : Cultural brand asset has impact on perceived quality

$\mathbf{H}_{2}$ : Brand awareness has impact on perceived quality

$\mathbf{H}_{3}$ : Cultural brand asset has impact on brand awareness

$\mathbf{H}_{4}$ : Cultural brand asset has impact on brand association

$\mathbf{H}_{5}$ : Brand awareness has impact on perceived association

$\mathbf{H}_{6}$ : Perceived quality has impact on brand loyalty 
$\mathbf{H}_{7}$ : Brand awareness has impact on brand loyalty

$\mathbf{H}_{\mathbf{8}}$ : Brand association has impact on brand loyalty

$\mathbf{H}_{\mathbf{9}}$ : Individual's similarity to brand has impact on brand loyalty

$\mathbf{H}_{10}$ : Life congruency has impact on brand loyalty

$\mathbf{H}_{11}$ : Customer satisfaction has impact on brand loyalty

$\mathbf{H}_{\mathbf{1 2}}$ : Individual's similarity to brand has impact on customer satisfaction

$\mathbf{H}_{13}$ : Life congruency has impact on customer satisfaction

$\mathbf{H}_{14}$ : Cultural brand asset has impact on perceived quality through brand awareness

$\mathbf{H}_{15}$ : Cultural brand asset has impact on brand association through brand awareness

$\mathbf{H}_{16}$ : Brand awareness has impact on brand loyalty through perceived quality

$\mathbf{H}_{17}$ : Brand awareness has impact on brand loyalty through brand association

$\mathbf{H}_{18}$ : Individual's similarity to brand has impact on brand loyalty through customer satisfaction

$\mathbf{H}_{19}$ : Life congruency has impact on brand loyalty through customer satisfaction

According to theoretical framework of study, the conceptual model of the study is as follows:

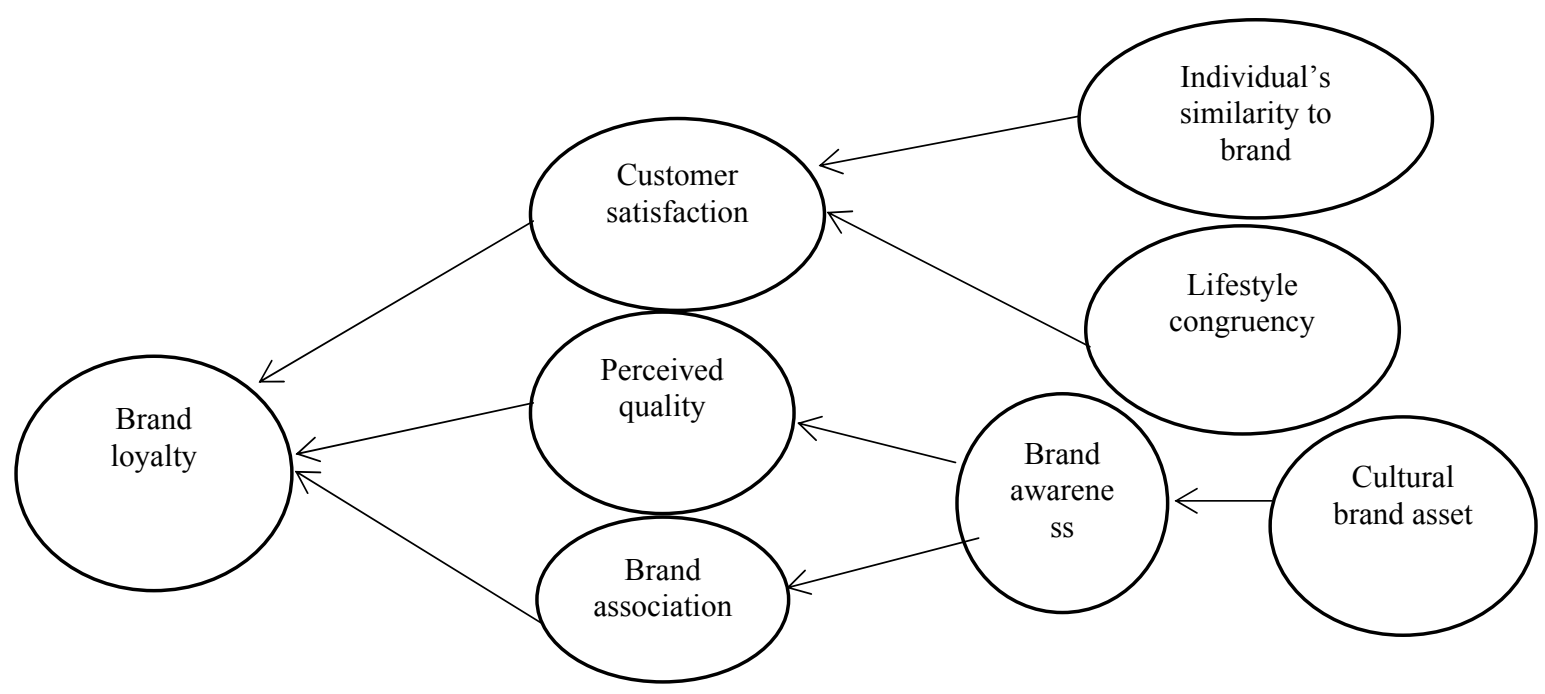

Figure 1. Conceptual model (Buil et al., 2013; Kladou \& Kehagias, 2014; Nam et al., 2011)

\section{Method}

This research is applied in terms of goal since it examines theoretical structures in practical and actual contexts and situations. The aim of this study is to find correlation among some variables (Investigating of factors affecting loyalty of Mehr chain hotels quests in Yazd). This study is descriptive and examines the relationship between variables. It is correlational in terms of implementation. Considering time of study, it is cross-sectional study.

\section{Population and Samples of Study}

The population of this research is Iranian and foreign guests of Mehr chain hotels of Yazd. Simple and stratified types of probability (random) sampling method were used in this study. 
As population size of study is unknown, sample size of study was determined using Cochran formula in which 385 subjects were selected, while 400 subjects were considered.

\section{Data Collection}

In this study, data are primary. Questionnaire was used to collect data and it was distributed among samples. This study is survey type in terms of data collection. This questionnaire has 10 questions for cultural brand asset, 5 questions for brand awareness, 4 questions for perceived quality, 9 questions for brand association, 3 questions for perceived value, 3 questions for brand personality, and 3 questions for hotel association. In addition, 3 questions were considered for brand loyalty, 3 questions for individual's similarity to brand, 3 questions for lifestyle congruency, and 2 questions for customer satisfaction. Field method is used as method of collecting data. According to supervisor's view on questionnaire, Cronbach's alpha was used to determine the reliability of questionnaire.

If alpha coefficient is more than .7, questionnaire has acceptable reliability. Table 1 shows Cronbach's alpha and the number of questions of whole questionnaire and questionnaire variables. Since Cronbach's alpha of the whole questionnaire and variables is greater than .7, the test has an acceptable reliability.

Table 1

Calculation of Reliability Of Questions

\begin{tabular}{lccc}
\multicolumn{1}{c}{ Variable } & $\begin{array}{c}\text { Number of } \\
\text { questionnaire } \\
\text { questions }\end{array}$ & Number of questions & Cronbach's alpha \\
\hline Cultural brand asset (CBA) & $1-10$ & 10 & .79 \\
Brand awareness (BAwa) & $11-15$ & 5 & .77 \\
Perceived quality (PQ) & $16-19$ & 4 & .85 \\
Brand association (Bass) & $20-28$ & 9 & .78 \\
Brand loyalty (BL) & $29-31$ & 3 & .77 \\
Individual's similarity to brand(ISC) & $32-34$ & 3 & .85 \\
Life style congruence (LSC) & $35-37$ & 3 & .88 \\
Customer satisfaction (CS) & $38-39$ & 2 & .84 \\
Whole questionnaire & & 39 & .91 \\
\hline
\end{tabular}

\section{Data Analysis}

In this study, descriptive statistics, frequency table, and pie charts were used to describe demographic data of study. To examine the variables, t- test was used and data were analyzed using SPSS18 software. The relationships among variables and factors were verified by using confirmatory factor analysis and structural equation modeling technique through LISREL 8.72 software. This software is one of the most popular software to implement the models involving testing the hypothesis to assess the simultaneous, direct, and indirect relationships among the variables. In addition, Sobel test was used to examine the mediating role of variables.

\section{Findings of the Study}


In this section, the examined variables were compared with intermediate measurement scale of t-test. Before examining the hypotheses, accuracy of model was evaluated. Then, hypotheses of study were tested.

\section{Comparison of the Study Variables with Intermediate Measurement Scale}

One-sample t-test to compare mean observed among variables of study with theoretical mean of measurement scale shows the significance level smaller than.05, the mean of all variables, except for lifestyle congruency, is significantly different from theoretical mean. Therefore, all variables are significantly higher than moderate level and lifestyle congruency is the moderate level. Then, confirmatory factor analysis was performed for the variable of brand association. Based on fit indices, confirmatory analysis output of brand association variable shows that model has an appropriate fitness. Additionally, $\mathrm{t}$ statistic value for all questions was higher than 1.96, as a result, it is significant. Extracted results show that absolute value of the $t$ statistic for all relationships is higher than 1.96 and the variance value explained for each variable by latent variable is acceptable value. Therefore, the model has a good fitness and the construct validity of brand association variable was confirmed.

\section{Main Model}

Before testing the hypotheses, it is necessary to be insured of accuracy of measurement model. Confirmatory factor analysis was conducted by using path analysis for significance test on factors.

\section{Measurement Model Investigation along with $\mathbf{T}$ Statistic, Standard Coefficient and Error Value}

As presented in Figure 2, path coefficient of each item with its variable has value higher than 1.96. Based on results of measurement models, all items have $t$ statistic higher than 96.1 and determination coefficient value of them is appropriate. Therefore, none of the items is removed from the model. On other hand, based on standard coefficients (factorial loads) the index that has the highest factorial load has greater share in the relevant variable measurement and the index that has the lower coefficients will have less share in the relevant variable measurement. 


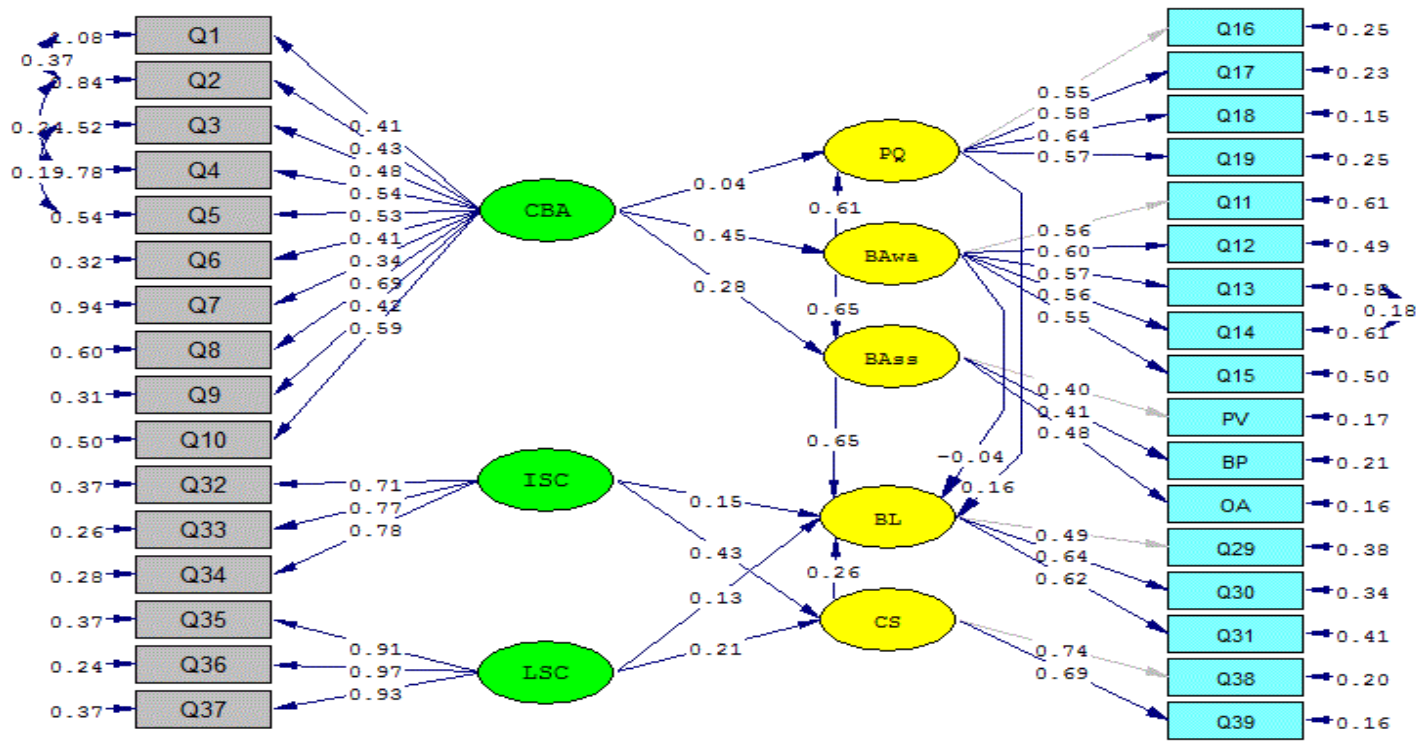

Chi-Square=1274.77, $d f=475$, P-value=0.00000, RMSEA=0.062

Figure 2. Model in non-standard estimation mode

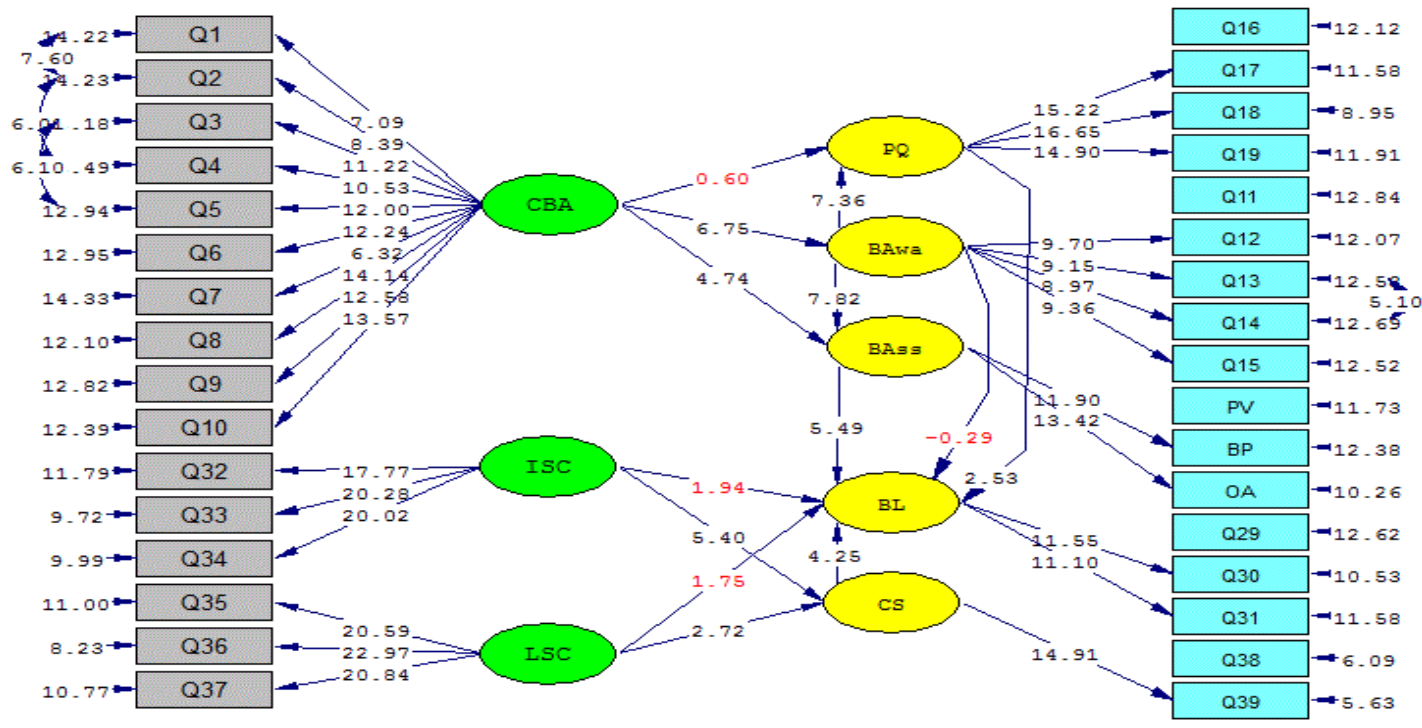

Chi-Square=1274.77, df=475, P-value=0.00000, RMSEA=0.062

Figure 3. Model in estimating the significance values mode (t-value)

As indicated in Figure 3, numbers on paths show t-value for each path. If this value is not significant, it is shown with red color in the software output. In this analysis, $t$ statistic for 9 paths was higher than 1.96. As a result, it is significant. However, it is not significant for three variables of brand awareness, individual's similarity to brand, and lifestyle congruency to brand loyalty and cultural brand asset to perceived quality. 


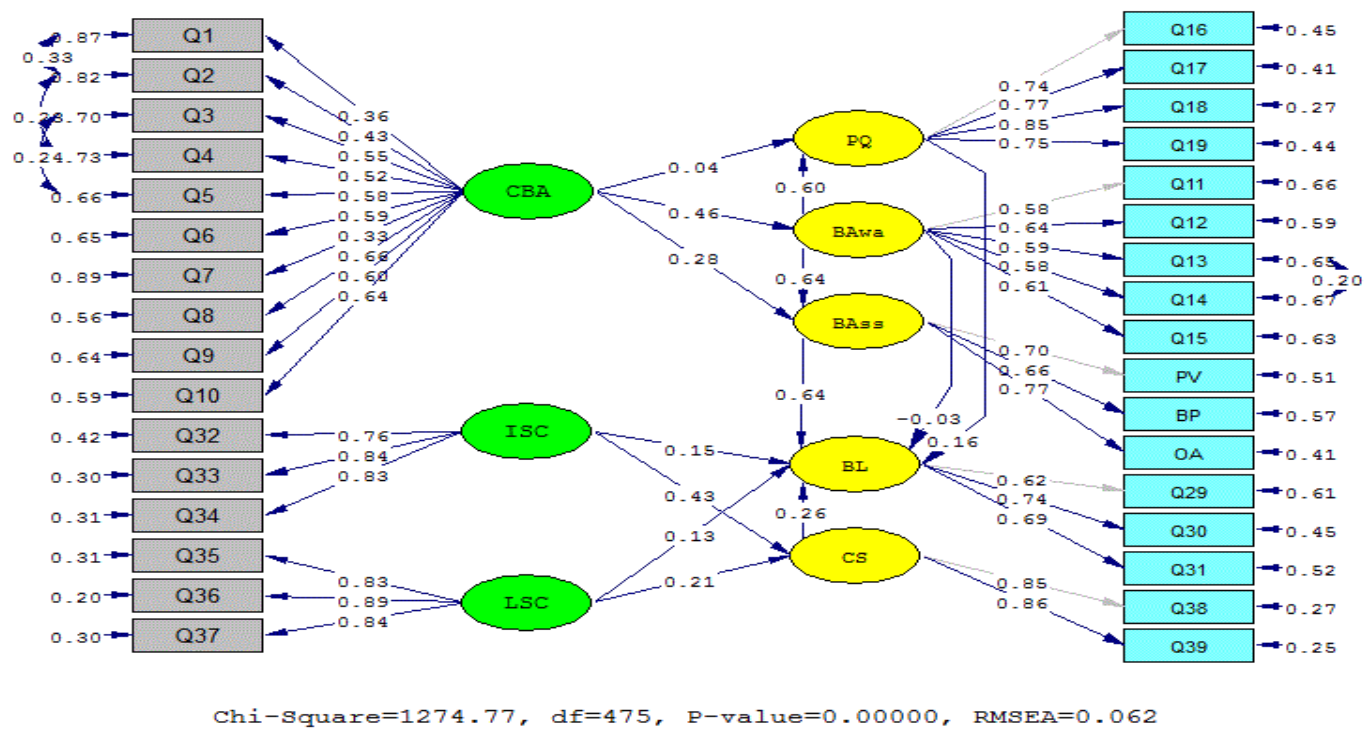

Figure 4. Model in standard coefficients mode

Figure 4 shows the general model in the standard estimation mode. Comparing observed variables is possible only in the standard estimation mode. Given the standard coefficients, it can be said that variables of brand awareness (.64) and cultural brand asset (.28) have respectively the highest impact on brand association variable and brand association variables (.64), customer satisfaction (.26), and perceived quality (.16) have respectively the highest on brand loyalty. On other hand, individual's similarity to brand (.43) has more impact than customer satisfaction variable (.21) compared to lifestyle congruency.

\section{Confirmation of Model}

Based on Table 2, degree of freedom value is 2.68 and is smaller than 3 that is appropriate value. The mean value of this index shows little difference among conceptual model of study with observed data of study. In addition, RMSEA value is .06 and smaller than .08. In addition, as value of RMSEA value is lower, model has more appropriate fitness, and indices (NFI - NNFI - IFI - CFI) are higher than 9.0 and index CFI and AGFI are higher than .8. Therefore, model has desirable fitness and it is confirmed.

Table 2

Investigation of Fit Indices

\begin{tabular}{cc}
\hline Reported value & Indices \\
\hline 1274.77 & Chi-square \\
475 & Degree of freedom \\
2.68 & Chi-square to degrees of freedom \\
0.062 & RMSEA \\
0.85 & GFI \\
0.82 & AGFI \\
0.93 & NFI \\
0.95 & NNFI \\
0.96 & IFI \\
0.96 & CFI \\
\hline
\end{tabular}


Table 3

Summary of Standard Coefficients, Determination Coefficients, Statistic T and Results of Test

\begin{tabular}{|c|c|c|c|c|c|}
\hline hypothesis & Path & 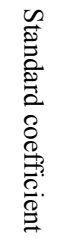 & 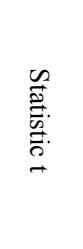 & 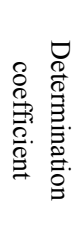 & Result \\
\hline 1 & Cultural brand asset $\leftarrow$ perceived quality & .04 & .60 & .38 & rejected \\
\hline 2 & brand awareness $\leftarrow$ perceived quality & .60 & 7.36 & .21 & confirmed \\
\hline 3 & Cultural brand asset $\leftarrow$ brand awareness & .46 & 6.75 & .66 & confirmed \\
\hline 4 & Cultural brand asset $\leftarrow$ brand association & .28 & 4.74 & .38 & confirmed \\
\hline 5 & brand awareness $\leftarrow$ brand association & .64 & 7.82 & & confirmed \\
\hline 6 & perceived quality $\leftarrow$ brand association & .16 & 2.53 & .74 & confirmed \\
\hline 7 & brand awareness $\leftarrow$ brand loyalty & -.03 & -0.29 & & rejected \\
\hline 8 & brand association $\leftarrow$ brand loyalty & .64 & 5.49 & & confirmed \\
\hline 9 & Individual's similarity to brand $\leftarrow$ brand loyalty & .15 & 1.94 & & rejected \\
\hline 10 & Lifestyle congruence $\leftarrow$ brand loyalty & .13 & 1.75 & & rejected \\
\hline 11 & Customer satisfaction $\leftarrow$ brand loyalty & .26 & 4.25 & & confirmed \\
\hline 12 & Individual's similarity to brand $\leftarrow$ customer satisfaction & .43 & 5.40 & .35 & confirmed \\
\hline 13 & Lifestyle congruence $\leftarrow$ customer satisfaction & .21 & 2.72 & & confirmed \\
\hline
\end{tabular}

Table 3 shows that coefficient of determination for perceived quality was estimated .38 , and it shows that cultural brand asset and brand awareness variables could explain $38 \%$ of perceived quality changes. According to $t$ statistic value, brand awareness has impact on perceived quality variable, while cultural brand asset had no significant impact. On the other hand, only $21 \%$ of the brand awareness changes are explained by cultural brand asset.

Accordingly, cultural brand asset and brand awareness variables explain $66 \%$ of cultural brand asset changes. Considering the standard coefficient value and $t$ statistic, brand awareness has more impact on brand association compared to cultural brand asset. Determination coefficient for brand loyalty also was estimated .74 indicating that variables of perceived quality, brand awareness, individual's similarity to brand, lifestyle congruency and customer satisfaction could explain $74 \%$ of the brand loyalty changes.

According to $t$ statistic and standard coefficient, the variables of brand association (.64), customer satisfaction (.26) and perceived quality (10.16) have respectively the highest impact on brand loyalty (the highest standard path coefficient), and the variables of brand awareness, individual's similarity to brand and lifestyle congruency had no significant impact. Variables of individual's similarity to brand and lifestyle congruency could explain only $35 \%$ of the customer satisfaction changes. Based on t statistic and standard coefficient value, individual's similarity to brand $(0.43)$ has more impact on customer satisfaction compared to lifestyle congruency $(.21 \%)$.

\section{Research Hypothesis Test}

After investigating and confirming the main model, the hypotheses of model were evaluated. As absolute value of the $t$ statistic is less than 1.96, null hypothesis is confirmed. If the 
absolute value of the t-statistic is greater than 1.96, null hypothesis is rejected, and considered variables will affect each other. The results of the first to thirteenth hypotheses testing were presented in Table 3 in the previous section. The results of other hypotheses test and mediating variables are interpreted in this section.

Table 4

Summary of Coefficient Estimation, T Statistic, Standard Coefficients and Results of Test

\begin{tabular}{|c|c|c|c|c|c|c|c|}
\hline \multirow[t]{2}{*}{ Hypothesis } & \multicolumn{2}{|r|}{ Path } & 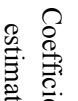 & \multirow{2}{*}{ 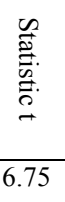 } & \multirow{2}{*}{$\begin{array}{l}\text { S } \\
i \rightarrow 1 \\
.06\end{array}$} & \multirow{2}{*}{ 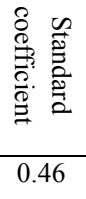 } & \multirow[t]{2}{*}{ Result } \\
\hline & 1 & Cultural brand asset $\rightarrow$ brand awareness & .45 & & & & \\
\hline 14 & 2 & brand awareness $\rightarrow$ perceived quality & .61 & 0.08 & .08 & 0.60 & Confirmed \\
\hline \multirow[b]{2}{*}{15} & 1 & Cultural brand asset $\rightarrow$ brand awareness & .45 & 6.75 & .06 & 0.46 & \multirow[b]{2}{*}{ Confirmed } \\
\hline & 2 & brand awareness $\rightarrow$ brand association & .65 & 7.82 & .08 & 0.64 & \\
\hline \multirow[b]{2}{*}{16} & 1 & brand awareness $\rightarrow$ perceived quality & .61 & 7.36 & .08 & 0.60 & \multirow[b]{2}{*}{ Confirmed } \\
\hline & 2 & perceived quality $\rightarrow$ brand loyalty & .16 & 2.53 & .05 & 0.16 & \\
\hline \multirow{2}{*}{17} & 1 & brand awareness $\rightarrow$ brand association & .65 & 7.82 & .08 & 0.64 & \multirow[b]{2}{*}{ Confirmed } \\
\hline & 2 & brand association $\rightarrow$ brand loyalty & .65 & 5.49 & .12 & .64 & \\
\hline \multirow[t]{2}{*}{18} & 1 & $\begin{array}{l}\text { Individual's similarity to brand } \rightarrow \text { Customer } \\
\text { satisfaction }\end{array}$ & .43 & 5.40 & .079 & .43 & \multirow{2}{*}{ Confirmed } \\
\hline & 2 & Customer satisfaction $\rightarrow$ brand loyalty & .26 & 4.25 & .061 & .26 & \\
\hline \multirow{2}{*}{19} & 1 & Lifestyle congruence $\rightarrow$ Customer satisfaction & .21 & 2.72 & .076 & .21 & \multirow[b]{2}{*}{ Confirmed } \\
\hline & 2 & Customer satisfaction $\rightarrow$ brand loyalty & .26 & 4.25 & .061 & .26 & \\
\hline
\end{tabular}

Table 5

Results of Sobel to Investigate the Effect of Mediating Variables

\begin{tabular}{cccccc}
\hline Hypothesis & Z test statistic & S.E & significance level & Indirect effect & Standard indirect effect \\
\hline 14 & 4.95 & .05 & .000 & .27 & .27 \\
15 & 5.09 & .05 & .000 & .29 & .29 \\
16 & 2.74 & .03 & .006 & .09 & .09 \\
17 & 4.38 & .09 & .000 & .42 & .41 \\
18 & 3.35 & .03 & .001 & .11 & .11 \\
19 & 2.31 & .02 & .020 & .05 & .05
\end{tabular}

In the fourteenth hypothesis, according to the Sobel test statistic (4.95) and the significance level (0.000) which is smaller than .05 , the null hypothesis is rejected, as presented in Table 5. Therefore, due to lack of significant direct relationship between the perceived quality and cultural brand asset in the model, brand awareness plays a mediating role and its indirect effect is equal to .27. As a result, cultural brand asset affects perceived quality through brand awareness at the 95\% confidence level. According to Sobel test statistic (5.09) and significant level (0.0) related to the fifteenth hypothesis that is smaller than .05 , null hypothesis is rejected. Therefore, due to significant direct relationship between cultural brand asset and brand association in the model, brand awareness variable plays mediating role slightly and its indirect impact is .29 . Therefore, cultural brand asset affects brand association through brand awareness at 95\% confidence level. In the sixteenth 
hypothesis, according to the Sobel test statistic (2.74) and the significance level (.006) which is smaller than .05 , the null hypothesis is rejected. Therefore, due to lack of significant direct relationship between the brand awareness and brand loyalty in the model, perceived quality plays the mediating role and its indirect effect is equal to .10. As a result, brand awareness affects brand loyalty through perceived quality at the $95 \%$ confidence level. According to Sobel test statistic (4.38) and significant level (.000) related to the seventeenth hypothesis that is smaller than .05 , null hypothesis is rejected. Therefore, due to lack of significant direct relationship between brand awareness and brand loyalty in the model, brand association plays a mediating role completely and its indirect impact is .41. Therefore, brand awareness affects brand loyalty through brand association at $95 \%$ confidence level.

In the eighteenth hypothesis, according to the Sobel test statistic (3.35) and the significance level (.001) which is smaller than .05 , the null hypothesis is rejected. Therefore, due to lack of significant direct relationship between the individual's similarity to brand and brand awareness in the model, customer satisfaction plays a mediating role completely and its indirect effect is equal to .11. As a result, individual's similarity to brand affects brand loyalty through customer satisfaction at the $95 \%$ confidence level. According to Sobel test statistic (2.31) and significant level (.02) related to the nineteenth hypothesis that is smaller than .05 , null hypothesis is rejected. Therefore, due to lack of significant direct relationship between lifestyle congruency and brand loyalty in the model, customer satisfaction plays a mediating role completely and its indirect impact is .06 . Therefore, lifestyle congruency affects brand loyalty through customer satisfaction at $95 \%$ confidence level.

\section{Discussion and Conclusion}

In the first hypothesis, the effect of cultural brand assets on perceived quality has been examined, and this hypothesis was finally rejected. This hypothesis is in line with the results of the research conducted by Cludio and Keghlias (2014). The results of the testing the hypotheses confirm the relationship between perceived quality and brand awareness in the second hypothesis. This result in in line with the study study conducted by Buil et al (2013).

Brand awareness increases the perceived quality of customer through shaping positive, strong, powerful association. The third hypothesis states that cultural brand asset has impact on brand awareness that this hypothesis was confirmed. This result is in line with results of studies conducted by Cludio and Keghlias (2014). In the fourth hypothesis, the relationship between cultural brand asset and brand association was confirmed, that it was consistent with results of the study conducted by Cludio and Keghlias (2014). The fifth hypothesis suggests the relationship between brand awareness and brand association. The results indicate that brand awareness has positive impact on brand association. The results of the studies conducted by Buil et al. (2013) and Rahimnia et al (2013) also confirmed this relationship. Chen et al.'s (2015) study also suggested the relationship between perceived quality and brand loyalty investigated as sixth hypothesis. In the relationship between perceived quality and brand loyalty, customer shows a response to brand based on a perception of brand quality, and due to positive relationships between these variables, if customer perceives the brand at high quality, he will show loyalty in purchasing that brand in the decision making process. The seventh hypothesis suggests the relationship between brand awareness and 
brand loyalty, while results rejected this relationship. In studies conducted by Chen et al (2015) and Ghaffari et al (2014), the relationship between these variables was confirmed. The presence of negative standard coefficient in their relationship will result in negative effects. In other words, in this study, brand awareness increased brand remembering during purchasing. The relationship between brand association and brand loyalty (hypothesis 8) was confirmed. This result is consistent with the results of a study conducted by Buil et al (2013). Ninth hypothesis suggests that individual's similarity to the brand has no significant correlation with brand loyalty. The presence of positive relationship between these variables has been proven is studies conducted by Chen et al. (2015) and Dehdashti, Salehi Sadaghiani, and Harandi (2012). In the tenth hypothesis, it was confirmed that lifestyle congruency has relationship with brand loyalty. In studies conducted by Chen et al. (2015) and Dehdashti et al. (2012), the positive relationship between them was confirmed. In the eleventh hypothesis, the relationship between customer satisfaction and brand loyalty was tested. The results confirmed this relationship. This hypothesis is consistent with studies conducted by Kim and Hyun (2011), Nam et al. (2011), Ghaffari et al. (2014), Dehdashti Shahrokh et al. (2012). Twelfth hypothesis suggests the effect of individual's similarity to brand on customer satisfaction. The results suggest positive relationship between them. Studies conducted by Ekinci et al. (2008), Nam et al. (2011), and Dehdashti Shahrokh et al. (2012) also confirm it. In the thirteenth hypothesis, the relationship between lifestyle congruency and customer satisfaction was confirmed. This is consistent with the results of studies conducted by Nam et al. (2011), and Dehdashti Shahrokh et al (2012). As lifestyle congruency and brand awareness increase, it can be expected that customer satisfaction to be increased and vice versa. The fourteenth hypothesis states that cultural brand asset affects perceived quality through brand awareness. This relationship was confirmed and it is consistent with the results of a study conducted by Cludio and Keghlias (2014). The relationship between cultural brand asset and brand association through brand awareness was confirmed (hypothesis 15), that it is consistent with the results of Cludio and Keghlias (2014). In the sixteenth hypothesis, the relationship between brand awareness and brand loyalty through perceived quality was confirmed that is consistent with the results of a study conducted by Buil et al. (2013). Increased brand awareness enhances the perceived quality leading to brand loyalty. Seventeenth hypothesis states that brand awareness has impact on brands association through brand loyalty. This hypothesis was confirmed and it is consistent with a research conducted by Buil et al. (2013). In the eighteenth hypothesis, the relationship between lifestyle congruency and brand loyalty through customer satisfaction was confirmed, it is in line with the studies conducted by Nam et al. (2011) and Dehdashti Sharokh et al. (2011). Lifestyle congruency increases loyalty of customers through customer satisfaction. Based on nineteenth hypothesis, there is a significant relationship between individual's similarity to brand and brand loyalty through customer satisfaction that these results are consistent with studies conducted by Nam et al. (2011) and Dehdashti Shahrokh et al. (2012).

\section{Recommendations}

No capital or asset is efficient for organization other than a powerful brand. This is very important in services especially in hotel. While a known and powerful brand for customer is 
not regarded as commitment for his future satisfaction, it could increase service purchase. Chain hotel managers should take steps to strengthen the hotel brand. Due to the positive relationship between the cultural brand asset and brand awareness, we can introduce potentials in Mehr chain hotels such as traditional context of hotel, being located in the center of Yazd historical context, vicinity to historical locations, history of hotels, holding more festivals in ceremonies and holding special tours, using media, environmental, and online advertising. By doing this, we can increase customers' awareness of brand. With regard to the impact of brand awareness on perceived quality and brand association, it is recommended that the managers of the hotels to integrate modern and ancient equipment and provide luxury materials and attractive arrangement for rooms of customers. In addition, capable and skilled staff cause that they can identify symbolic needs of customers and do their best in providing the service for customers. Accordingly, customers will receive the best facilities and pleasant experience of accommodation in hotel so that customers choose the Mehr chain hotel brand as the first brand when they reselect the hotel. Therefore, by returning to these hotels and offering them for others, their loyalty increases in this regard. With regard to the impact of the cultural brand asset on the perceived quality and brand association, we use following items in order to improve brand association in mind of customers of hotel.

Improving the internal space of hotel, using traditional dress and serving traditional foods especially Yazd city foods by staff of hotel, using traditional music in hotel, using handcrafts indicating that hotel is local and all of them belong to Yazd city. By doing this, we can create relaxation combined with the convenience in customers so that their loyalty to hotel increases.

With regard to relationships between individual's similarity to brand and brand loyalty and customer satisfaction, and considering the individual's similarity to brand through customer satisfaction, hotels managers must personalize their services to make them compatible with self-concept of customers. For example, internal space of hotels can be changed to be close with their self-concept. This can lead to higher satisfaction and memorable experience of hotel by customers leading to increased loyalty to hotel. The existence of the relationship between lifestyle congruency and brand loyalty and customer satisfaction, the impact of lifestyle congruency on brand loyalty through customer satisfaction, and in order to understand the needs of quests and developing appropriate services, it is recommended that lifestyle of potential quests to be examined and studied and hotels to be equipped with their lifestyles. It is also recommended that special facilities and equipment to be provided since hotel quests vary based on hotel level. In this situation, customers' satisfaction will be provided. Due to brand awareness impact on brand loyalty through perceived quality and brand association and in order to increase awareness of hotel quests we can take big steps in introducing and attracting organizational customers and Iranian and non-Iranian customers by using strong public communication with various organizations as well as signing contracts with travel tours and providing special offers. In addition, to attract more non-Iranian customers, besides holding Yazd tours, improved food quality, cleanliness of rooms, and improved communication with them, increasing the speed of internet and giving free internet can be considered in line with attracting more customers. Considering the close relationship between satisfaction and loyalty, to provide satisfaction for customers, continuous 
improvement process should be used in a way that not only passenger achieves to his needs and wants, but also we should take steps to meet his needs. Accordingly, satisfied customer becomes loyal customer and permanent customer. Such a person does advertising for hotel and causes increased net profit and increased number of customers in hotel. Considering the impact of cultural brand asset on perceived quality and brand association, holding different seminars and meetings in charities leads to introducing hotel for different groups and improvement of hotel name and positive attitude to hotel. With regard to the relationship between brand awareness and brand loyalty, the relationship with customers must be maintained. Special facilities can be considered for customers. For example, free accommodation can be considered for a customer or a special offer or prize such as free access to internet.

\section{Reference}

Ahn, T., Ekinci, Y., \& Li, G. (2013). Self-congruence functional congruence and destination choice. Journal of Business Research, 66(6),719-723.

Allameh, S. M, \& Noktedan, I. (2010). Investigating the effect of service quality on customer loyalty (case study of four-star and five star hotels of Isfahan). Business Management, 2(5), 90-75.

Assael, H. (1984). Consumer behavior and marketing action. Kent Publishing Company: Boston

Buil, I., de Chernatony, L., \& Martinze, E. (2013). Examining the role of advertising and sales promotion in brand equity creation. Journal of business research, 66(1), 115-122.

Chen, A., Peng, N., \& Hung, K. (2015). Examining tourist's loyalty toward cultural quarters. Annul of Tourism Research, 51, 51-63.

Dehdashti, S., Salehi Sadaghiani, J., \& Harandi, A. (2012). The effect of brand equity from a consumer perspective on brand loyalty and satisfaction in the hotel industry. Research Journal of Tourism Management, 91(17), 1-32.

Dehdashti Shahrokh, Z, Jafarzadeh, M, Bakhshizadeh, A. (2012). Investigating the point of view of social identity of the brand and its impact on the development of brand loyalty (the case study of manufacturing company of Kaleh). Research Journal of New Marketing, 2(2), 106-87.

Ekinci Y. L., Dawes, P. h. R., Massy, G. (2008). An extended model of antecedent and consequences of consumer satisfaction for hospitality services. European Journal of Marketing, 42(1-2), 35-68.

Ghaffari, M., Ranjbaran, B., \& Fathi, S. (2014). Providing a model to explain tourism destination brand equity (case study of Isfahan). Journal of Marketing Management, 10, 65-93.

Haghighi, M., Moghimi, S. M, \& Kymasy, M. (2003). Loyalty of service, quality of services and mediator role of customer satisfaction. Knowledge Management, 60, 53-72.

Hakala, U., Svensson, J., \& Vincze, Z. (2012). Consumer based brand equity and top of mind awareness across country analysis. Journal of Product and Brand Management, 21(6), 439-451.

Hosseini, M. H., \& Rezaie, M. (2011). Investigating the factors affecting brand loyalty in the market of dairy products. Business Management Perspective, 38(5), 57-69.

Huber, F., Vollhardt, K., Matthes, I., \& Vogle, J. (2010). Brand misconduct congruence in consumer brand relationship. Journal of Business Research, 63, 1113-1120.

Imani Khoshkhu, M. H., \& Ayubi Yazdi, H. (2010). Factors affecting tourism destination brand equity of Yazd. Journal of Tourism Studies, 13, 113-137.

Javanmard, H, Hosseini S. (2013). Determination of the relationship between store mental image, customer satisfaction distance and behavioral intentions of purchasers, Case study: Citizen chain-store Tehran. Journal of Marketing Management, 20, 85-101.

Khajouie, F., \& NaebZadeh, S. H. (2013). The impact of satisfaction and indifference (inertia) on customer loyalty, case study: Mobile phone. Journal of Marketing Management, 19, 29-46.

Kim, J. H., \& Hyun, Y. J. (2011). A model of investigate the influence of marketing mix effort and corporate image on brand equity on IT software sector. Industrial Marketing Management, 40, 424-438. 
Kladou, S., \& Kehagias, J. (2014). Developing a structural brand equity model for cultural destination. Journal of Destination Marketing \& Management, 3(1), 2-10.

Lu, A. C. C., Gursoy, D., \& Lu, C. Y. (2015). Authenticity perceptions brand equity and brand choice intention: The case of ethnic restaurants. International journal of hospitality management, 50(8), 36-45.

Moody, D, Mir-Kazemi, Z, Vahdani, M. (2015). The relationship between brand features and brand loyalty in sport shoes. Contemporary Studies on Sports Management, 9, 61-72.

MotahariNejad, F, Samadi, S, Tulani, Z, Pour Ashraf, Y. (2014). Examining the relationship of brand and its consumer, case study: Electric appliance. Journal of Marketing Management, 23, 127-148.

Nam J. Y., Ekinci, Y., \& Whatt, G. (2011). RAND equity, brand loyalty and consumer satisfaction. Annual of Tourism Research, 38(3), 1009-1030.

Oliver, R. L. (1999). Whence customer loyalty? Journal of Marketing, 63, 33-44. doi:10.2307/1252099

Rahimnia, F., Fatemi, S.R., \& Harandi, A. (2013). To assess the mutual impact of customer-oriented brand equity dimensions (five-star hotels of Mashhad metropolis, Tehran). University Management School of Business Management, 5(4), 1-20.

Ruzzier, M. K. (2010). Extending the tourism destination image concept into customer-based brand equity for a tourism destination. Economic research-Ekonomska Istraživanja, 23(3), 24-42.

Seric, M., Gil-Saura, I., \& Ruiz-Molina, M. E. (2014). How can integrated communication and advanced technology the creation customer based brand equity Evidence from the hospitality industry. International Journal of Hospitality Management, 39, 144-156.

SeyedJavadein, S. R, \& Shams, R. (2007). The determinants of sports shoes brand equity among younger groups. Humanities and Social Sciences Research Management, 25, 73-96.

Youl, H. H., Jhon, J., Janda, S., \& Siva, M. (2009). The effect of advertising on brand loyalty in services. European of Business Research, 45(4), 673-691.

ZarghamBoroujeni, H., \& Barzani, H. (2013). Tourism pathology in Iran. Research Journal of New Marketing, 3(1), 63-80. 